\title{
Threshold weight for starvation-triggered metamorphosis in the yellow-spotted longicorn beetle, Psacothea hilaris (Coleoptera: Cerambycidae)
}

\author{
Florence Njeri Munyiri, Wataru Asano, Yoshinori Shintani ${ }^{\dagger}$ and Yukio Ishikawa* \\ Laboratory of Applied Entomology, Graduate School of Agricultural and Life Sciences, The University of Tokyo; Tokyo \\ 113-8657, Japan \\ (Received 3 February 2003; Accepted 23 June 2003)
}

\begin{abstract}
The development of 4th stadium Psacothea hilaris larvae under various feeding and starving regimens was investigated to determine whether there is a threshold weight for metamorphosis. In larvae fed ad libitum, 56\% of individuals spent a mean of $13 \mathrm{~d}$ in the 4th stadium and $18 \mathrm{~d}$ in the 5 th stadium before pupation, whereas the rest remained in the 4 th stadium for $24 \mathrm{~d}$ and pupated. When starved upon ecdysis to the 4th stadium, no larvae molted to the 5th stadium and most eventually died without pupation. In contrast, when larvae were fed for $1 \mathrm{~d}$ and then starved, $47 \%$ prematurely metamorphosed into small pupae after a mean of $18 \mathrm{~d}$ in the 4 th stadium. Pupation success from the 4th stadium increased as the feeding period was extended, reaching $97 \%$ in the larvae that had fed for four days. All these pupae gave rise to small but morphologically normal adults. The relationships between the weight changes of experimental larvae during starvation and their pupation success suggested the threshold weight for metamorphosis to be $180 \mathrm{mg}$. The adaptive significance of premature pupation in starved P. hilaris is discussed as a life history strategy under unpredictable food conditions for larval growth.
\end{abstract}

Key words: Psacothea hilaris; premature pupation; starvation; threshold weight; survival

\section{INTRODUCTION}

Food shortage is a constraint that insects often have to contend with in nature. Starvation in many lepidopteran larvae results in delayed metamorphosis (Beck, 1950; Lower, 1961; Jones et al., 1980; Cymborowski et al., 1982; Morita and Tojo, 1985). In the tobacco hornworm Manduca sexta, for example, a body weight of $5 \mathrm{~g}$ is a proximate cue for metamorphosis (Nijhout and Williams, 1974). If larvae of this insect do not attain this size at the initial stage of the 5th stadium (normal last larval stadium), they undergo supernumerary larval molts, which in nature probably allow more time for the individuals to search for food and pursue further growth (Nijhout, 1975; for other species see: Blakley and Goodner, 1978; Blakley, 1981; Fischer and Fiedler, 2001). Some species of dermestid beetles such as Trogoderma glabrum are known to repeat larval molts into increasingly smaller individuals if deprived of food for extended periods of time, and when given food, resume growth and metamorphosis (Beck, 1971, 1972).
In contrast to the above species, two coleopteran species, a mushroom beetle Dacne picta and a dung beetle Onthophagus taurus, have been reported to shorten their larval period, instead of prolonging it, and pupate at smaller sizes when food supply is exhausted (Sato and Suzuki, 2001; Shafiei et al., 2001). More recently, we found that the yellow-spotted longicorn beetle Psacothea hilaris, also pupated prematurely upon starvation (Shintani et al., 2003). Since the number of species reported to show such a phenomenon is limited, little is known about starvation-induced premature metamorphosis.

$P$. hilaris is an important pest of mulberry and fig trees in Japan. Female beetles lay their eggs in the subcortical tissues of the trunk and the neonate larvae bore tunnels within the trunks. At $25^{\circ} \mathrm{C}$ and under a long day photoperiod ( $15 \mathrm{~h}$ light $: 9 \mathrm{~h}$ dark), about half of normally fed $P$. hilaris larvae pupate from the 4th stadium and the remainder pupate after an additional larval molt to the 5th stadium (Shintani et al., 1996a,b). The mechanism that dictates whether the larvae pupate from the 4th or the

\footnotetext{
* To whom correspondence should be addressed at: E-mail: ayucky@mail.ecc.u-tokyo.ac.jp

$\dagger$ Present address: Hokuriku Research Center, National Agricultural Research Center, Joetsu, Niigata 943-0193, Japan
} 
5th larval stadium remains unknown.

$P$. hilaris larvae that have fed for the first few days of the 4th stadium appear to acquire competence for metamorphosis; upon starvation, they terminate larval life and pupate prematurely (Shintani et al., 2003). Moreover, when 4th stadium larvae are provided with a low nutritive diet after having fed on a normal diet for a few days, they tend to avert molting to the next larval stadium and pupate earlier than those continuously given a normal diet (Shintani et al., 2003). These results suggest that only the first few days of feeding during the 4th stadium are sufficient for larvae to acquire the competence for metamorphosis. However, the physiological process determining the acquisition of the competence has remained unknown.

Based on previous findings, we hypothesized that there is a threshold weight that $P$. hilaris larvae must attain in order to gain the competence for metamorphosis. In the present study, we tested this hypothesis by examining growth, molting and metamorphosis of $P$. hilaris under various feeding and starvation regimens.

\section{MATERIALS AND METHODS}

Insect rearing. A colony of $P$. hilaris was established from more than 20 adults collected from a mulberry field at Ino $\left(33.5^{\circ} \mathrm{N}, 133.4^{\circ} \mathrm{E}\right)$ in 1996. Insects were reared on commercial artificial diets for the silkworm (Silkmate $2 \mathrm{~S}^{\circledR}$ until the 3rd stadium and thereafter changed to Insecta $L F^{\circledR}$, Nihon
Nosan, Co., Yokohama) following the method of Shintani et al. (1996a). Neonate larvae placed individually in Petri dishes containing fresh diet were reared at $60 \%$ relative humidity, $25^{\circ} \mathrm{C}$ and under a long day photoperiod $(15 \mathrm{~h}$ light and $9 \mathrm{~h}$ dark, 15L : 9D).

Effect of starvation after some feeding in the 4th stadium. Larvae were reared under the long day photoperiod at $25^{\circ} \mathrm{C}$ until the end of the $3 \mathrm{rd}$ stadium. On the day of ecdysis to the 4 th stadium (day 0 ), they were randomly assigned to either the experimental or control group. Control larvae were provided with food ad libitum during the entire larval development. Experimental larvae were weighed and transferred to clean Petri dishes with no food or moisture source on days $0,1,2,3$, or 4 of the 4th stadium (Fig. 1, Experiment A, S, 1F-S, 2F-S, 3F-S, 4F-S). All experimental and control larvae were checked daily for molting and/or pupation, and their body weights were recorded after each molt. To trace the daily body weight changes of larvae, S, 1F-S and 4F-S experiments were repeated once more. The general state of health of the larvae was estimated by their response to probing with a forceps. For those individuals that died, the date and their developmental stage were also recorded.

Effect of re-feeding after starvation on the development of larvae. To examine if acquisition of the competence for metamorphosis is limited to the initial stage of the 4th stadium, newly ecdysed 4th stadium larvae were starved for 6 or 20 days, and

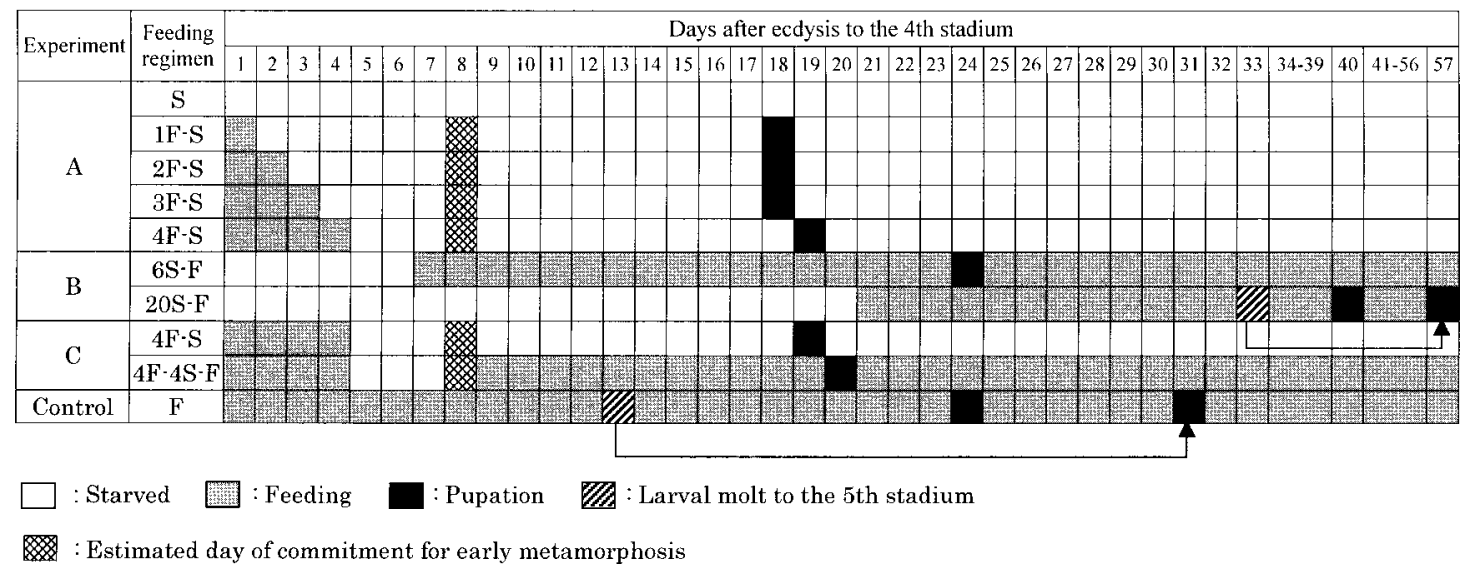

Fig. 1. Schematic representation showing the development of 4th stadium $P$. hilaris larvae under various feeding and starvation regimens at $25^{\circ} \mathrm{C}$ and $15 \mathrm{~h}$ light: $9 \mathrm{~h}$ dark. Between 20 and 33 P. hilaris larvae were subjected to each feeding regimen within $12 \mathrm{~h}$ of ecdysis to the 4th stadium. Feeding and starvation are designated by $\mathrm{F}$ and S, respectively. For example, 4F-4S-F indicates that newly ecdysed 4th stadium larvae were fed for four days, starved for four days and then fed ad libitum. Only typical patterns of pupation are shown in each feeding regimen. 
Table 1. Developmental success of the 4th stadium $P$. hilaris larvae under different feeding and starvation regimes ${ }^{\mathrm{a}}$

\begin{tabular}{|c|c|c|c|c|c|c|c|c|c|c|}
\hline \multirow{2}{*}{$\begin{array}{l}\text { Feeding } \\
\text { regime }^{b}\end{array}$} & \multirow{2}{*}{$N$} & \multirow{2}{*}{$\begin{array}{l}\text { Weight after } \\
\text { ecdysis to } \\
\text { 4th stadium } \\
\text { (mg) }\end{array}$} & \multirow{2}{*}{$\begin{array}{l}\text { Weight at } \\
\text { initiation of } \\
\text { starvation } \\
(\mathrm{mg})\end{array}$} & \multirow{2}{*}{$\begin{array}{c}\% \text { larvae } \\
\text { molted to } \\
\text { 5th stadium }\end{array}$} & \multirow{2}{*}{$\begin{array}{c}\% 5 \text { th } \\
\text { stadium } \\
\text { larvae } \\
\text { pupated }\end{array}$} & \multicolumn{2}{|c|}{$\begin{array}{l}\text { Larval period } \\
\text { (day) }\end{array}$} & \multirow{2}{*}{$\begin{array}{l}\text { Overall } \\
\text { pupation } \\
\text { rate }(\%)\end{array}$} & \multirow{2}{*}{$\begin{array}{l}\text { Pupal } \\
\text { weight }^{\mathrm{d}} \\
(\mathrm{mg})\end{array}$} & \multirow{2}{*}{$\begin{array}{l}\text { Pupal } \\
\text { period } \\
\text { (day) }\end{array}$} \\
\hline & & & & & & 4th & $4 \mathrm{th}+5 \mathrm{th}^{\mathrm{c}}$ & & & \\
\hline S & 30 & $189 \pm 54 \mathrm{a}$ & $189 \pm 54 \mathrm{a}$ & $\begin{array}{c}0 \\
(0)\end{array}$ & - & $\begin{array}{c}19.5 \pm 2.1 \mathrm{~b} \\
(2)\end{array}$ & $\overline{(0)}$ & 7 & $135 \pm 7 \mathrm{a}$ & $11.5 \pm 0.7 \mathrm{a}$ \\
\hline $1 \mathrm{~F}-\mathrm{S}$ & 30 & $186 \pm 49 a$ & $257 \pm 66 b$ & $\begin{array}{c}0 \\
(0)\end{array}$ & - & $\begin{array}{c}17.9 \pm 1.7 \mathrm{a} \\
(14)\end{array}$ & $\overline{(0)}$ & 47 & $136 \pm 44 a$ & $10.9 \pm 0.6 \mathrm{a}$ \\
\hline $2 \mathrm{~F}-\mathrm{S}$ & 26 & $185 \pm 39 a$ & $306 \pm 75 \mathrm{c}$ & $\begin{array}{c}4 \\
(1)\end{array}$ & 0 & $\begin{array}{c}18.0 \pm 2.4 \mathrm{a} \\
(20)\end{array}$ & $\overline{(0)}$ & 77 & $171 \pm 45 b$ & $11.0 \pm 0.8 \mathrm{a}$ \\
\hline $3 \mathrm{~F}-\mathrm{S}$ & 29 & $183 \pm 44$ a & $311 \pm 93 \mathrm{c}$ & $\begin{array}{l}17 \\
(5)\end{array}$ & $\begin{array}{l}17 \\
(1)\end{array}$ & $\begin{array}{c}18.2 \pm 1.6 \mathrm{a} \\
(24)\end{array}$ & $\begin{array}{l}32 \\
(1)\end{array}$ & 86 & $188 \pm 55 \mathrm{~b}$ & $11.2 \pm 0.7 \mathrm{a}$ \\
\hline $4 \mathrm{~F}-\mathrm{S}$ & 32 & $196 \pm 46 a$ & $351 \pm 81 \mathrm{~d}$ & $\begin{array}{c}3 \\
(1)\end{array}$ & 0 & $\begin{array}{c}19.0 \pm 1.9 \mathrm{a} \\
(31)\end{array}$ & $\overline{(0)}$ & 972 & $219 \pm 54 \mathrm{c}$ & $11.4 \pm 1.4 \mathrm{a}$ \\
\hline $\mathrm{F}$ & 27 & $205 \pm 63 \mathrm{a}$ & - & $\begin{array}{c}56 \\
(15)\end{array}$ & $\begin{array}{l}100 \\
(15)\end{array}$ & $\begin{array}{c}23.8 \pm 2.1 \mathrm{~b} \\
(12)\end{array}$ & $\begin{array}{c}30.5 \pm 3.0^{\mathrm{e}} \\
(15)\end{array}$ & 1003 & $392 \pm 65 d$ & $11.5 \pm 1.3 \mathrm{a}$ \\
\hline
\end{tabular}

${ }^{a}$ Values are means \pm S.D. Means followed by the same letter in the same column are not significantly different at $5 \%$ level by Tukey-Kramer's multiple range test. Numbers of insects that pupated are shown in parentheses.

${ }^{\mathrm{b}}$ See Fig. 1 for the feeding and starvation regimes.

${ }^{\mathrm{c}}$ Total duration of the 4th and 5th stadia of larvae that pupated in the 5th stadium.

${ }^{\mathrm{d}}$ Values for those individuals that pupated in the 4th stadium.

${ }^{\mathrm{e}}$ Duration of the 4 th and 5 th stadia: $12.6 \pm 1.9 \mathrm{~d}$ and $17.9 \pm 3.5 \mathrm{~d}$, respectively.

thereafter provided with food ad libitum (Fig. 1, Experiment B, 6S-F, 20S-F). Next, to examine whether starvation-triggered metamorphosis can be suppressed if the larvae are fed again, a group of 4th stadium larvae were given food for four days, then deprived of food for four days and again allowed access to food (Fig. 1, Experiment C, 4F-4S$\mathrm{F})$. In this experiment, ingestion of food was checked by observing the midgut through the integument of larvae.

Data analysis. Statistical analyses were conducted using a software package, Statview ${ }^{\circledR}$ (SAS Institute Inc., NC, USA). Data were analyzed by ANOVA, and the significance of differences among means was determined by Tukey-Kramer's multiple range test. In the text and figures, values are presented as means \pm standard deviation.

\section{RESULTS}

\section{Effect of total starvation after different periods of feeding in the 4th stadium (Experiment A)}

When food was supplied to 4th stadium $P$. hilaris larvae ad libitum, all pupated successfully after showing one of these two patterns; $56 \%$ of larvae molted to the 5 th stadium after a mean of
$12.6 \mathrm{~d}$ and subsequently pupated $17.9 \mathrm{~d}$ later, whereas the remainder pupated after a mean of $23.8 \mathrm{~d}$ without molting to the 5 th larval stadium (Table 1).

The timing of starvation significantly affected the survival of larvae (Table 1). Most of the larvae that never had access to food in the 4th stadium eventually succumbed to death without undergoing metamorphosis (Table 1, S; mean survival time $=$ $28.7 \pm 3.2$ days, $n=28$ ). In contrast, $47 \%$ of the larvae that fed for one day in the 4th stadium pupated successfully (Table 1, 1F-S). Pupation success increased to $77 \%$ after feeding for two days (2F-S), and four days of continuous feeding in the 4th stadium was sufficient to support metamorphosis in $97 \%$ of the larvae (4F-S). This value was similar to that of the larvae fed ad libitum $(100 \%, \mathrm{~F})$.

The pupae obtained from the $4 \mathrm{~F}-\mathrm{S}$ regimen were significantly heavier than those obtained from the $1 \mathrm{~F}-\mathrm{S}, 2 \mathrm{~F}-\mathrm{S}$ and $3 \mathrm{~F}-\mathrm{S}$ regimens, but they were still significantly smaller than the fed controls (Table 1). All controls and experimental pupae produced morphologically normal adults except for the difference in size. Adult weights were strictly dependent on pupal weights (data not shown; $r^{2}=0.98$, $p<0.001)$. 
The relationships between the weight of a respective larva at the start of starvation and its pupation success suggested the presence of a threshold weight for metamorphosis (Fig. 2). None of the larvae weighing $<180 \mathrm{mg}$ survived to pupation, while all the larvae weighing $>360 \mathrm{mg}$ successfully pupated. The pupation success of larvae weighing in between was apparently dependent on the timing of food deprivation. When larvae of a similar weight were compared, those that were starved later in the 4 th stadium had a higher chance of pupation (Fig. 2 ). This result suggests that the destiny of the starved larvae was not determined simply by the weight after a specific period of starvation, other-

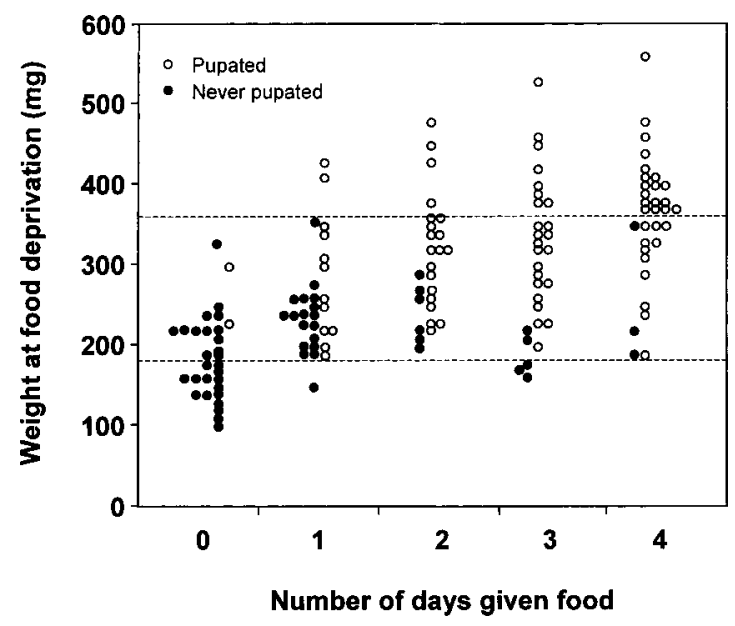

Fig. 2. Pupation success of all experimental P. hilaris larvae in Experiment A as a function of larval weight at the start of starvation and the day of starvation. Each symbol represents an individual. Symbols are shifted horizontally to avoid overlapping. wise, larvae of a similar weight should have displayed similar pupation success regardless of the timing of food deprivation.

Starvation greatly reduced the proportion of individuals that molted to the 5th larval stadium (Table 1). While $56 \%$ of larvae molted to the 5 th stadium when given food ad libitum, only a few molted to the 5th stadium when starved. Furthermore, the few that molted to the 5th stadium rarely survived to pupation (Table 1).

In those individuals that successfully pupated from the 4th larval stadium, starvation significantly decreased the duration of the 4th stadium ( $F=17.6$, $p<0.001$, Table 1). Whereas the duration of the 4 th stadium for control individuals was 24 days, the larvae in the $1 \mathrm{~F}-\mathrm{S}, 2 \mathrm{~F}-\mathrm{S}, 3 \mathrm{~F}-\mathrm{S}$ and $4 \mathrm{~F}-\mathrm{S}$ regimens pupated in 18-19 days (see Fig. 1). On the other hand, no significant difference was found in the duration of the pupal stage between experimental and control animals $(F=0.8, p>0.05$, Table 1$)$.

\section{Effect of re-feeding after starvation on the de- velopment of larvae (Experiment $B$ )}

All larvae that were starved for six days in the 4th stadium pupated successfully after re-feeding (Table 2, 6S-F). Interestingly, all but one individual pupated from the 4th stadium. All the larvae, except two, withstood starvation for 20 days and pupated after re-feeding (20S-F). However, their developmental process was apparently different from that of the controls or larvae in the 6S-F regimen. The larvae in the 20S-F regimen gained weight very slowly (Table 2): they gained only $16 \mathrm{mg}$

Table 2. Effect of starvation with subsequent furnishing of food on growth and development of P. hilaris larvae

\begin{tabular}{|c|c|c|c|c|c|c|c|c|c|c|}
\hline \multirow{3}{*}{$\begin{array}{l}\text { Feeding } \\
\text { regime }^{b}\end{array}$} & \multirow{3}{*}{$N$} & \multirow{3}{*}{$\begin{array}{l}\text { Weight after } \\
\text { ecdysis to } \\
\text { 4th stadium } \\
\text { (mg) }\end{array}$} & \multirow{3}{*}{$\begin{array}{l}\text { Weight } \\
\text { after } \\
\text { starvation } \\
\text { (mg) }\end{array}$} & \multirow{3}{*}{$\begin{array}{l}\text { Weight } 1 \mathrm{~d} \\
\text { after } \\
\text { re-feeding } \\
\quad(\mathrm{mg})\end{array}$} & \multirow{3}{*}{$\begin{array}{l}\text { Weight } 4 \mathrm{~d} \\
\text { after } \\
\text { re-feeding } \\
(\mathrm{mg})\end{array}$} & \multirow{3}{*}{$\begin{array}{c}\% \\
\text { molted } \\
\text { to } 5 \text { th } \\
\text { stadium }\end{array}$} & \multirow{2}{*}{\multicolumn{2}{|c|}{$\begin{array}{l}\text { Larval period } \\
\text { (day) }\end{array}$}} & \multirow{2}{*}{\multicolumn{2}{|c|}{$\begin{array}{c}\text { Pupal weight (mg) } \\
\text { Final stadium }\end{array}$}} \\
\hline & & & & & & & & & & \\
\hline & & & & & & & 4th & $4 \mathrm{th}+5 \mathrm{th}^{\mathrm{c}}$ & 4 th & 5 th \\
\hline $6 \mathrm{~S}-\mathrm{F}$ & 22 & $169 \pm 39 a$ & $121 \pm 28 \mathrm{a}$ & $208 \pm 71 \mathrm{a}$ & $337 \pm 73 \mathrm{a}$ & $\begin{array}{c}5 \\
(1)\end{array}$ & $\begin{array}{c}23.5 \pm 4.7 \mathrm{a} \\
(21)\end{array}$ & $\begin{array}{r}36.0 \\
(1)\end{array}$ & $\begin{array}{c}290 \pm 48 b \\
(21)\end{array}$ & $\begin{array}{r}420 \\
(1)\end{array}$ \\
\hline $20 \mathrm{~S}-\mathrm{F}^{*}$ & 20 & $166 \pm 43 a$ & $93 \pm 26 b$ & $109 \pm 39 b$ & $246 \pm 86 \mathrm{~b}$ & $\begin{array}{l}65 \\
(13)\end{array}$ & $\begin{array}{c}39.8 \pm 16.5 b \\
(5)\end{array}$ & $\begin{array}{c}56.7 \pm 6.3^{\mathrm{d}} \\
(13)\end{array}$ & $\begin{array}{c}175 \pm 65 \mathrm{c} \\
(5)\end{array}$ & $\begin{array}{c}426 \pm 76 \mathrm{a} \\
(13)\end{array}$ \\
\hline $\mathrm{F}$ & 25 & $183 \pm 31 \mathrm{a}$ & - & - & - & $\begin{array}{c}52 \\
(13)\end{array}$ & $\begin{array}{c}24.3 \pm 2.1 \mathrm{a} \\
(12)\end{array}$ & $\begin{array}{c}32.3 \pm 2.7 \\
(13)\end{array}$ & $\begin{array}{c}367 \pm 86 \mathrm{a} \\
(12)\end{array}$ & $\begin{array}{c}410 \pm 36 a \\
\text { (13) }\end{array}$ \\
\hline
\end{tabular}

\footnotetext{
${ }^{\text {a }}$ See the footnote to Table $1 .{ }^{*}$ Two individuals died during starvation on days 18 and 19

${ }^{\mathrm{b}}$ See Fig. 1 for the feeding and starvation regimes.

${ }^{\mathrm{c}}$ Total duration of the 4 th and 5 th stadia of larvae that pupated in the 5 th stadium.

${ }^{\mathrm{d}}$ Duration of the 4 th and 5th stadia: $33.3 \pm 4.0 \mathrm{~d}$ and $23.4 \pm 3.6 \mathrm{~d}$, respectively.
} 
(17\% of the pre-feeding body weight) after re-feeding for one day, whereas those in the $6 \mathrm{~S}-\mathrm{F}$ regimen gained $87 \mathrm{mg}(72 \%)$. A marked difference between the two experimental groups was also found in the percentage of larvae that molted to the 5th larval stadium. As much as $65 \%$ of larvae in the $20 \mathrm{~S}-\mathrm{F}$ regimen entered the 5 th stadium compared with only $5 \%$ in the $6 \mathrm{~S}-\mathrm{F}$ regimen. The weights of pupae formed from the 5th stadium larvae in the 20S-F regimen were, although very variable, comparable with their counterparts in the control (Table 2).

The duration of the 4th stadium was similar for controls and larvae in the 6S-F regimen; however, pupae formed from the latter were significantly smaller than control pupae (Table 2). It is clear from this result that commitment for metamorphosis did not occur during the six days of starvation; otherwise pupation should have occurred much earlier.

The very low growth rate observed after re-feeding in the 20S-F regimen suggests that the physiological state of larvae changed when they were starved for a long period. They appeared to have entered quiescence, a state of non-programmed developmental arrest. When the weight at the time of re-feeding was compared, those that pupated from the 4 th stadium were heavier $(119 \pm 11 \mathrm{mg}, n=5)$ than those that molted to the 5th stadium $(88 \pm 25$ $\mathrm{mg}, n=13 ; F=12.2, p<0.001)$. This suggests that upon re-feeding, lighter larvae tended to undergo an additional larval molt rather than pupation.
Effect of alternate feeding and starvation on larval development (Experiment $C$ )

When 4th stadium larvae were given a second opportunity to feed after four days of feeding and four days of starvation (4F-4S-F), only $50 \%$ fed again, whereas the rest, instead, purged their guts to prepare for pupation. Those larvae that fed again also discontinued feeding in a few days, purged their guts and consequently pupated. The percentage of larvae that pupated from the 4th stadium was similar for the $4 \mathrm{~F}-4 \mathrm{~S}-\mathrm{F}$ and $4 \mathrm{~F}-4 \mathrm{~S}$ regimens $(>95 \%$, Table 3$)$. Both groups of larvae completed the 4th stadium much earlier than the control $(F=$ $31.2, p<0.001$, Table 3 ). The pupae obtained from the $4 \mathrm{~F}-4 \mathrm{~S}-\mathrm{F}$ regimen were significantly heavier than those from the $4 \mathrm{~F}-\mathrm{S}$ regimen $(F=22.6, p<$ 0.001 , Table 3$)$. In the $4 \mathrm{~F}-4 \mathrm{~S}-\mathrm{F}$ regimen, interestingly, whether or not larvae fed again did not cause a significant difference in the pupal weight $(F=0.9$, $p>0.05$ ). This is because at the 2 nd opportunity for feeding, only lighter larvae $(130-280 \mathrm{mg}$, mean $213 \mathrm{mg}, n=13)$ re-fed for a few days but heavier ones (280-380 mg, mean $316 \mathrm{mg}, n=13)$ did not.

\section{DISCUSSION}

It was noted that the occurrence of pupation in the 4th stadium was concentrated in two discrete periods irrespective of the feeding regimens (Fig. $1)$. The control and larvae in the 6S-F regimen pupated with a mean period of 24 days, while all others except for larvae in the $20 \mathrm{~S}-\mathrm{F}$ regimen pupated with a mean period of 18-20 days. These results strongly suggest that commitment for premature

Table 3. Effect of alternate feeding and starvation on larval development of P. hilaris ${ }^{\mathrm{a}}$

\begin{tabular}{|c|c|c|c|c|c|c|c|c|}
\hline \multirow{2}{*}{$\begin{array}{l}\text { Feeding } \\
\text { regime }^{b}\end{array}$} & \multirow[t]{2}{*}{$N$} & \multirow{2}{*}{$\begin{array}{l}\text { Weight after } \\
4 \text { days } \\
\text { feeding }(\mathrm{mg})\end{array}$} & \multirow{2}{*}{$\begin{array}{l}\% \text { entered } \\
5 \text { th } \\
\text { stadium }\end{array}$} & \multirow{2}{*}{$\begin{array}{l}\% \text { pupated } \\
\text { from } 4 \text { th } \\
\text { stadium }\end{array}$} & \multicolumn{2}{|c|}{$\begin{array}{l}\text { Larval period } \\
\text { (day) }\end{array}$} & \multicolumn{2}{|c|}{$\begin{array}{c}\text { Pupal weight (mg) } \\
\text { Final stadium }\end{array}$} \\
\hline & & & & & 4th & $4 \mathrm{th}+5 \mathrm{th}^{\mathrm{c}}$ & 4th & 5 th \\
\hline $4 \mathrm{~F}-\mathrm{S}$ & 29 & $369 \pm 73 a$ & $\begin{array}{c}3 \\
(1)\end{array}$ & $\begin{array}{c}97 \\
(28)\end{array}$ & $\begin{array}{c}18.8 \pm 2.8 \mathrm{a} \\
(28)\end{array}$ & $\begin{array}{l}26 \\
(1)\end{array}$ & $\begin{array}{c}220 \pm 56 \mathrm{a} \\
(28)\end{array}$ & $\begin{array}{r}280 \\
(1)\end{array}$ \\
\hline 4F-4S-F & 25 & $343 \pm 79 a$ & $\begin{array}{c}4 \\
(1)\end{array}$ & $\begin{array}{c}96 \\
(24)\end{array}$ & $\begin{array}{c}19.7 \pm 3.7 \mathrm{a} \\
(24)\end{array}$ & $\begin{array}{l}31 \\
(1)\end{array}$ & $\begin{array}{c}277 \pm 53 \mathrm{~b} \\
(24)\end{array}$ & $\begin{array}{r}300 \\
(1)\end{array}$ \\
\hline $\mathrm{F}$ & 26 & $374 \pm 37 a$ & $\begin{array}{c}50 \\
(13)\end{array}$ & $\begin{array}{c}50 \\
(13)\end{array}$ & $\begin{array}{c}24.4 \pm 3.2 \mathrm{~b} \\
(13)\end{array}$ & $\begin{array}{c}31.2 \pm 4.7 \\
\quad(13)\end{array}$ & $\begin{array}{l}384 \pm 60 \mathrm{c} \\
(13)\end{array}$ & $\begin{array}{c}455 \pm 81 \\
(13)\end{array}$ \\
\hline
\end{tabular}

\footnotetext{
${ }^{a}$ See the footnote to Table 1.

${ }^{\mathrm{b}}$ See Fig. 1 for the feeding and starvation regimes.

${ }^{\mathrm{c}}$ Total duration of the 4 th and 5 th stadia of larvae that pupated in the 5 th stadium.
} 
pupation occurred at a specific timing, which is different from that of the fed control. A marked effect of temporary food deprivation in the 4F-4S-F regimen suggests that being in a starved state between day 5 and day 8 is crucial for the induction of premature pupation. Since the destiny of most larvae in the 4F-4S-F regimen was already irreversible when they were given a second opportunity for feeding on day 8 , commitment for starvation-triggered pupation should have occurred between day 5 and day 8. Considering that it takes some time for the larvae to fall into 'a starved state' after food deprivation, and that feeding on and after day 7 appears to suppress starvation-triggered premature pupation (see 6S-F in Fig. 1), commitment for premature pupation is likely to have occurred on day 7 or day 8 .

Analysis of the body weight changes of starved larvae suggested that the development of starved larvae can be explained by the following hypotheses (Fig. 3): (1) When a starved larva weighs more than $180 \mathrm{mg}$ on the day of commitment (day 7 or 8 ), it is destined for pupation. (2) In contrast, commitment is suspended in a larva weighing less than $180 \mathrm{mg}$, and development is eventually arrested if starvation persists. The mean weight of larvae in the S, $1 \mathrm{~F}-\mathrm{S}$ and $4 \mathrm{~F}-\mathrm{S}$ regimens on day 8 was 120 , 180 and $260 \mathrm{mg}$, respectively (Fig. 3). Few larvae in the $\mathrm{S}$ regimen weighed $>180 \mathrm{mg}$, while almost

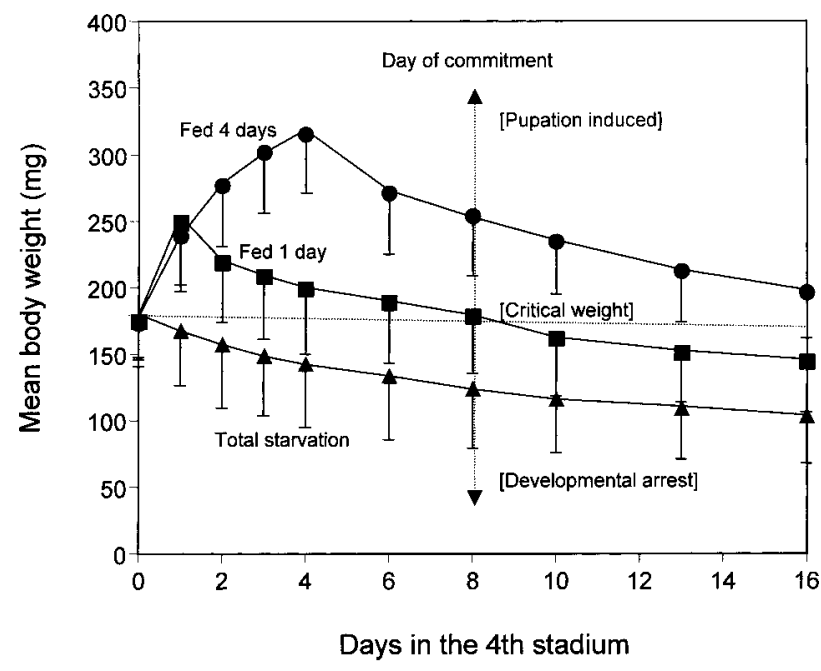

Fig. 3. Body weight as a determinant of larval destiny on the day of commitment - a hypothetical explanation. The threshold weight and the day of commitment are assumed to be $180 \mathrm{mg}$ and day 8 , respectively. The lines show the changes of mean body weights of the larvae. Vertical bars indicate standard deviation. all larvae in the $4 \mathrm{~F}-\mathrm{S}$ regimen weighed $>180 \mathrm{mg}$. In the $1 \mathrm{~F}-\mathrm{S}$ regimen, about $50 \%$ of larvae weighed $>180 \mathrm{mg}$ on day 8 . These findings are concordant with the results that $7 \%, 47 \%$ and $96 \%$ of larvae in the $\mathrm{S}, 1 \mathrm{~F}-\mathrm{S}$ and $4 \mathrm{~F}-\mathrm{S}$ regimens, respectively, achieved metamorphosis. The pupation success of the larvae weighing between 180 and $360 \mathrm{mg}$ was dependent on the timing of food deprivation (Experiment A, Fig. 2). This phenomenon may be explained as follows: When larvae are deprived of food earlier, they would have to wait a longer period of time for the day of commitment. Hence, a larger portion of larvae could not maintain a body weight of $>180 \mathrm{mg}$ while waiting, and consequently failed to pupate.

$P$. hilaris larvae shorten their larval life and pupate at a smaller body size if the food supply is limited. In nature, $P$. hilaris larvae do not move from one host plant to another and have to complete their development in the trunks into which they have been deposited as eggs. Under such circumstances, it seems highly adaptive to shorten larval development time and form a small pupa, rather than to remain as a larva, in the event of exhaustion or deterioration of its food resources.

In a coleopteran, Onthophagus taurus (Scarabaeidae), final (3rd) stadium larvae exceeding 80 mg shorten their larval life and pupate upon starvation (Shafiei et al., 2001). Similarly, in Dacne picta (Coleoptera: Erotylidae), larval development is shortened if final (4th) stadium larvae are starved after feeding for two days (Sato and Suzuki, 2001). In both $O$. taurus and D. picta, larvae have to be in their normal final stadium to undergo pupation upon starvation. The final larval stadium of $P$. hilaris is not fixed under normal conditions; they pupate either after the 4th or 5th stadium under long day conditions. In contrast to the 4th stadium $P$. $h i$ laris larvae, which have to feed for the first few days to acquire the competence for pupation, newly ecdysed 5th stadium larvae can pupate without any feeding (Shintani et al., 2003). This finding can be explained if we assume that there is no stadium-dependent change in threshold weight for metamorphosis; the 5th stadium larvae have far exceeded the threshold weight right from the day of ecdysis.

As already noted, starvation-triggered early metamorphosis has been reported in coleopteran species of Erotylidae (D. picta; Sato and Suzuki, 2001) and Scarabaeidae (O. taurus; Shafiei et al., 
2001). The present finding in P. hilaris is the first example in a third coleopteran family, Cerambycidae. In $O$. taurus, the larvae must complete their larval life by consuming the dung into which their mothers have deposited them as eggs (Sowig, 1996; Moczek, 1998). The larvae of D. picta complete their life in a short-lasting food resource, mushrooms (Sato et al., 1999). Thus, in nature, the larvae of these species are similarly faced with substantial variation in food resource availability. Therefore, premature pupation under limited food supply may be a common strategy among coleopteran insects that face restrictive food resource, and is worth further investigation in other species.

\section{ACKNOWLEDGEMENTS}

We thank Dr. M. Harris of North Dakota University for critical comments on the manuscript. We thank Dr. S. Tatsuki of our laboratory for his encouragement throughout this study.

\section{REFERENCES}

Beck, S. D. (1950) Nutrition of the European corn borer, Pyrausta nubilalis (Hbn.). II. Some effects of diet on larval growth characteristics. Physiol. Zool. 23: 353-361.

Beck, S. D. (1971) Growth and retrogression in larvae of Trogoderma glabrum (Coleoptera: Dermestidae). 2. Factors influencing pupation. Ann. Entomol. Soc. Am. 64: 946-949.

Beck, S. D. (1972) Growth and retrogression in larvae of Trogoderma glabrum (Coleoptera: Dermestidae). 3. Ecdysis and form determination. Ann. Entomol. Soc. Am. 65: $1319-1324$.

Blakley, N. (1981) Life history significance of size-triggered metamorphosis in milkweed bugs (Oncopeltus). Ecology 62: 57-64.

Blakley, N. and S. R. Goodner (1978) Size-dependent timing of metamorphosis in milkweed bugs (Oncopeltus) and life history implications. Biol. Bull. 155: 499-510.

Cymborowski, B., M. Bogus, N. E. Beckage, C. M. Williams and L. M. Riddiford (1982) Juvenile hormone titers and metabolism during starvation induced supernumerary larval molting of the tobacco hornworm Manduca sexta. J. Insect Physiol. 28: 129-135.

Fischer, K. and K. Fiedler (2001) Effects of larval starvation on adult life-history traits in the butterfly species Lycaena tityrus (Lepidoptera: Lycaenidae). Entomol. Gener. 25: 249-254.
Jones, D., G. Jones and G. Bhaskaran (1980) Induction of supernumerary molting by starvation in Manduca sexta larvae. Entomol. Exp. Appl. 28: 259-267.

Lower, H. F. (1961) The pathology of starvation in the army worm, Persicana ewingii. J. Insect Physiol. 3: 129-142.

Moczek, A. P. (1998) Horn polyphenism in the beetle Onthophagus taurus; larval diet quality and plasticity in parental investment determine adult body size and male horn morphology. Behav. Ecol. 9: 636-641.

Morita, M. and S. Tojo (1985) Relationship between starvation and supernumerary ecdysis and recognition of the penultimate-larval instar in the common cutworm, Spodoptera litura. J. Insect Physiol. 31: 307-313.

Nijhout, H. F. (1975) A threshold size for metamorphosis in the tobacco hornworm, Manduca sexta. Biol. Bull. 149: 214-225.

Nijhout, H. F. and C. M. Williams (1974) Control of molting and metamorphosis in the tobacco hornworm Manduca sexta (L.): growth of the last instar larva and the decision to pupate. J. Exper. Biol. 61: 481-491.

Sato, T., N. Shinkaji and H. Amano (1999) Selective oviposition by adult females and larval growth of Dacne picta Crotch (Coleoptera: Erotylidae) on different growing stages of the shiitake mushroom, Lentinula edodes. Appl. Entomol. Zool. 34: 1-7.

Sato, T. and A. Suzuki (2001) Effect of starvation and feeding of larvae during 4th stadia on pupation and adult size in Dacne picta (Coleoptera: Erotylidae). Appl. Entomol. Zool. 36: 189-197.

Shafiei, M., A. P. Moczek and H. F. Nijhout (2001) Food availability controls the onset of metamorphosis in the dung beetle Onthophagus taurus (Coleoptera: Scarabaeidae). Physiol. Entomol. 26: 172-180.

Shintani, Y., Y. Ishikawa and S. Tatsuki (1996a) Larval diapause in the yellow-spotted longicorn beetle, Psacothea hilaris Pascoe (Coleoptera: Cerambycidae). Appl. Entomol. Zool. 31: 489-494.

Shintani, Y., F. N. Munyiri and Y. Ishikawa (2003) Change in significance of feeding during larval development in the yellow-spotted longicorn beetle, Psacothea hilaris (Pascoe) (Coleoptera: Cerambycidae). J. Insect Physiol. 49: 975-981.

Shintani, Y., S. Tatsuki and Y. Ishikawa (1996b) Geographic variation of photoperiodic response in larval development of the yellow-spotted longicorn beetle, Psacothea hilaris Pascoe (Coleoptera: Cerambycidae). Appl. Entomol. Zool. 31: 495-504.

Sowig, P. (1996) Brood care in the dung beetle Onthophagus vacca (Coleoptera: Scarabaeidae); the effect of soil moisture on time budget, nest structure, and reproductive success. Ecography 19: 254-258. 